\title{
Inhibitory Activity for Chitin Synthase II from Saccharomyces cerevisiae by Tannins and Related Compounds
}

\author{
Eui-Il Hwang ${ }^{1}$, Byung-Tae Ahn³ ${ }^{3}$ Hyang-Bok Lee', Young-Kook Kim², Kyong-Soon Lee³, Song-Hae Bok², \\ Young-Tae Kim¹, Sung-Uk Kim,*

\footnotetext{
${ }^{1}$ Antibiotics Research Laboratory, Korea Research Institute of Bioscience and Biotechnology, Yusung, Taejon, Korea

${ }^{3}$ College of Pharmacy, Chungbuk National University, Cheongju, Korea
} \\ ${ }^{2}$ Cardiovascular Research Laboratory, Korea Research Institute of Bioscience and Biotechnology, Yusung, Taejon, Korea
}

Received: September 11, 2000; Accepted: December 15, 2000

\begin{abstract}
In the course of search for potent inhibitors of chitin synthase II from natural resources, seven tannins and related compounds were isolated from the aerial part of Euphorbia pekinensis and identified as gallic acid (1), methyl gallate (2), 3-Ogalloyl-(-)-shikimic acid (3), corilagin (4), geraniin (5), quercetin-3-O-(2"-O-galloyl)- $\beta$-D-glucoside (6), and kaempferol-3-O(2"-O-galloyl)- $\beta$-D-glucoside (7). These and nine related compounds, (-)-quinic acid (8), (-)-shikimic acid (9), ellagic acid (10), kaempferol (11), quercetin (12), quercitrin (13), rutin (14), quercetin-3-O-( 2 "-O-galloyl)- $\beta$-D-rutinoside (15) and 1,3,4,6-tetra- $O$-galloyl- $\beta$-D-glucose (16), were evaluated for the inhibitory activity against chitin synthase II and III. They inhibited chitin synthase II with IC 50 values of 18-206 $\mu \mathrm{M}$, except for two organic acids, (-)-quinic acid (8) and (-)-shikimic acid (9). Among them, 3-O-galloyl-(-)-shikimic acid (3) was the most potent inhibitor against chitin synthase II of Saccharomyces cerevisiae with an IC 50 value of $18 \mu \mathrm{M}$. The inhibition appears to be selective for chitin synthase II, as they did not appreciably inhibit chitin synthase III.
\end{abstract}

Key words: Euphorbia pekinensis, Euphorbiaceae, chitin synthase II, chitin synthase III, chitin synthase II inhibitor, tannins, antifungal agents.

\section{Introduction}

Chitin is an important structural polysaccharide of fungal cell walls. Although the content of chitin in the cell wall varies from species to species, it has been shown to be indispensable for the maintenance of the fungal cell wall integrity. Its synthesis constitutes a model for morphogenesis and provides a potential target in antifungal chemotherapy (1). Chitin is synthesized by chitin synthases I, II, and III in Saccharomyces cerevisiae (2). Chitin synthase I is involved in the repair of damaged chitin, chitin synthase II plays important roles in primary septum formation, and chitin synthase III is required for all other chitin synthases, including the formation of glucanchitin linkage. Thus, chitin synthases II and III are essential enzymes for cell division, whereas chitin synthase I is not. Therefore, specific inhibitors of chitin synthases II and III

Planta Med 67 (2001) 501-504

(C) Georg Thieme Verlag Stuttgart · New York ISSN: 0032-0943 might be interesting lead compounds for the development of effective antifungal agents.

As a part of our continuing efforts to discover naturally occurring new antifungal agents, we have screened for chitin synthase II inhibitors in higher plants. We report herein on the isolation, structural elucidation, and chitin synthases II and III activities of the isolates from Euphorbia pekinensis Rupr.

\section{Materials and Methods}

Chemicals

UDP-[U- $\left.{ }^{14} \mathrm{C}\right]-\mathrm{N}$-acetylglucosamine $(400,000 \mathrm{cpm} / \mu \mathrm{mol})$ was purchased from New England Nuclear (NEN) (DuPont, U.S.A). Trypin, trypsin inhibitor, and $\mathrm{N}$-acetylglucosamine were purchased from Sigma Chemical Co. (St. Louis, MO, U.S.A). Cobalt acetate was purchased from Showa Chemical Inc. (Japan). All other chemicals used in this study were of analytical grade.

\section{Chitin synthases II and III assay}

The assays of chitin synthases II and III prepared from recombinant S. cerevisiae ECY38-38A (pAS6) and ECY38-38A (pWJC6), respectively, were conducted according to the method of Choi and Cabib (3). The reaction mixtures contained 32 mM Tris- $\mathrm{HCl}$ (pH 8.0), 1.6 mM cobalt acetate, 1.0 mM UDP-[U$\left.{ }^{14} \mathrm{C}\right]-\mathrm{N}$-acetylglucosamine, $2 \mu \mathrm{L}$ of trypsin $(2 \mathrm{mg} / \mathrm{mL})$, and $20 \mu \mathrm{L}$ of membrane suspension in a total volume of $46 \mu \mathrm{L}$. Mixtures were incubated for $15 \mathrm{~min}$ at $30^{\circ} \mathrm{C}$. Proteolysis was stopped by addition of a 2.0 -fold excess of soybean trypsin inhibitor, and $\mathrm{N}$-acetylglucosamine was added to a final concentration of $32 \mathrm{mM}$, followed by incubation at $30^{\circ} \mathrm{C}$ for $90 \mathrm{~min}$. The insoluble chitin formed was assayed by the measurement of radioactivity after addition of $1 \mathrm{~mL}$ of cold $10 \%$ trichloroacetic acid and filtration through a glass fiber filter (Whatman GF/ C). For chitin synthase III activity (3), the assay was performed the same as for chitin synthase II, except that $32 \mathrm{mM}$ Tris- $\mathrm{HCl}$ ( $\mathrm{pH} 7.5$ ) and $4.3 \mathrm{mM}$ magnesium acetate were used. Blank values were obtained from the reaction containing solvents only. Percent inhibition of chitin synthases II and III was calculated by substracting the blank value from the control or test sample values. 
$\%$ Inhibition $=\left[1-\frac{\text { Sample }(\mathrm{cpm})-\text { Blank }(\mathrm{cpm})}{\text { Control }(\mathrm{cpm})-\text { Blank }(\mathrm{cpm})}\right] \times 100$

Each test compound was solubilized in $25 \% \mathrm{MeOH}$ or $25 \%$ DMSO to make stock solution $(1 \mathrm{mg} / \mathrm{mL})$ and $14 \mu \mathrm{L}$ of the stock solution were used to give the final concentration of $280 \mu \mathrm{g} / \mathrm{mL}$. Also, to determine $\mathrm{IC}_{50}$ values, a 2 -fold serial dilution was made with each test compound (4). The inhibitory activities are shown as average values in duplicates obtained from two independent experiments

\section{Plant material}

The aerial part of Euphorbia pekinensis Rupr. [ = Galarhoeus pekinensis (Rupr.) Hara] was collected at Mt. Sobaeck of Gangwon Province, Korea. A voucher specimen has been deposited under No. CNUP-151 in College of Pharmacy, Chungbuk National University, Korea.

\section{Extraction and isolation}

Melting points were determined on a Büchi 510-K melting point apparatus. FAB-MS were measured on a VG Trio 2 instrument. Optical rotations were measured on a Jasco DIP-181 digital polarimeter. The NMR spectra were obtained on a Bruker AMX 300 spectrometer $\left(300 \mathrm{MHz}\right.$ ) using acetone- $d_{6} /$ $\mathrm{D}_{2} \mathrm{O}$ and DMSO- $d_{6} / \mathrm{D}_{2} \mathrm{O}$. Chemical shifts are given in ppm using TMS as internal standard. Sephadex LH-20 $(20-100 \mu)$ (Pharmacia Fine Chemical Co.), MCI-gel CHP 20P (75-100 $\mu$ ) (Mitsubishi Chemical Industries Co.), TSK-gel Toyopearl HW 40F $(30-60 \mu)$ (Tosoh Co.), and Avicel cellulose (Funakoshi) were used for column chromatography.

The dried and milled sample ( $9 \mathrm{~kg}$ ) was soaked in $80 \%$ aqueous acetone $(40 \mathrm{~L})$ at room temperature for 5 days. The acetone was removed in vacuo and insoluble materials such as chlorophylls and waxes in aqueous phase were eliminated by filtration. The filtrate was concentrated in vacuo to yield a dark residue ( $298 \mathrm{~g}$ ) having inhibitory activity for chitin synthase II by $50-60 \%$ at $280 \mu \mathrm{g} / \mathrm{mL}$. The residue was suspended in $50 \% \mathrm{MeOH}$ and subjected to Sephadex LH-20 column chromatography $(300 \mathrm{~g})$ with a gradient of $\mathrm{H}_{2} \mathrm{O} / \mathrm{MeOH}(1: 1$ to $100 \% \mathrm{MeOH}, \mathrm{v} / \mathrm{v}, 1 \mathrm{~L}$ each eluent) to give two active fractions, which inhibited chitin synthase II by more than $60 \%$ at $280 \mu \mathrm{g} / \mathrm{ml}$; fraction 1 (50\% MeOH eluent, $35 \mathrm{~g}$ ) and fraction 2 (70\% $\mathrm{MeOH}$ eluent, $43 \mathrm{~g}$ ). Fraction 1 was recharged on $\mathrm{MCI}-$ gel CHP 20P (350 g) and eluted stepwise with a gradient of $\mathrm{H}_{2} \mathrm{O} / \mathrm{MeOH}$ (2:8 to $100 \% \mathrm{MeOH}, \mathrm{v} / \mathrm{v}, 1 \mathrm{~L}$ each eluent) to give two active fractions, which inhibited chitin synthase II by $70 \%$ at $280 \mu \mathrm{g} / \mathrm{ml}$; subfractions $1-1(50 \% \mathrm{MeOH}$ eluent, $1.8 \mathrm{~g})$ and $1-2$ (50-60\% MeOH eluent, $750 \mathrm{mg}$ ). Subfraction 1-1 was further purified by Sephadex LH-20 chromatography (180 g) with a gradient of $\mathrm{H}_{2} \mathrm{O} / \mathrm{MeOH}(2: 8$ to $100 \% \mathrm{MeOH}, \mathrm{v} / \mathrm{v}, 1 \mathrm{~L}$ each eluent) to give compound 1 (50\% $\mathrm{MeOH}$ eluent, $761 \mathrm{mg}$ ) and 2 (60\% MeOH eluent, $288 \mathrm{mg}$ ). Subfraction $1-2$ was further purified by Sephadex LH-20 (75 g) eluting with $50 \%$ $\mathrm{MeOH}(1 \mathrm{~L})$ to give compounds $3(150 \mathrm{mg})$ and $4(63 \mathrm{mg})$. Fraction 2 was recharged on MCI-gel CHP 20P (430 g) and eluted stepwise with a gradient of $\mathrm{H}_{2} \mathrm{O} / \mathrm{MeOH}(2: 8$ to $100 \%$ $\mathrm{MeOH}, \mathrm{v} / \mathrm{v}, 1 \mathrm{~L}$ each eluent) to give two active fractions, which inhibited by more than $70 \%$ at $280 \mu \mathrm{g} / \mathrm{mL}$; subfractions $2-1$ (80\% MeOH eluent, $7.9 \mathrm{~g}$ ), and $2-2$ (90\%-100\% MeOH eluent,
2.0 g). Subfraction $2-1$ was further purified by Sephadex LH20 (150 g) column chromatography with $50 \% \mathrm{MeOH}(1.5 \mathrm{~L})$ to give compound $5(7.0 \mathrm{~g})$ and one active fraction $(800 \mathrm{mg})$. The active fraction was chromatographed on TSK-gel Toyopearl HW 40F (40 g) using $\mathrm{H}_{2} \mathrm{O} / \mathrm{EtOH}(2: 8$ to $100 \% \mathrm{EtOH}, \mathrm{v} / \mathrm{v}, 500$ $\mathrm{mL}$ each eluent) to give compound 6 (80\% EtOH eluent, 321 $\mathrm{mg}$ ). Subfraction $2-2$ was further purified by Sephadex LH-20 $(150 \mathrm{~g})$ with EtOH $(1 \mathrm{~L})$ to give one active fraction $(1.5 \mathrm{~g})$. The active fraction was chromatographed on TSK-gel Toyopearl HW 40F (45 g) using $\mathrm{H}_{2} \mathrm{O} / \mathrm{EtOH}(1: 1$ to $100 \% \mathrm{EtOH}, \mathrm{v} / \mathrm{v}$, $500 \mathrm{ml}$ each eluent), and the $80 \% \mathrm{EtOH}$ eluate $(1.2 \mathrm{~g}$ ) was rechromatographed on Avicel cellulose (36 g) using $\mathrm{H}_{2} \mathrm{O} / \mathrm{AcOH}$ $(98: 2, \mathrm{v} / \mathrm{v}, 400 \mathrm{ml}$ eluent) column chromatography to give compound 7 ( $0.9 \mathrm{~g})$.

\section{Other test compounds}

To obtain further information on the inhibitory activity for chitin synthases II and III, two tannins, quercetin-3-O-(2"-galloyl)- $\beta$-D-rutinoside (15), and 1,3,4,6-tetra- $O$-galloyl- $\beta$-D-glucose (16) were obtained from College of Pharmacy, Chungbuk National University. (-)-Quinic acid (8), (-)-shikimic acid (9), ellagic acid (10), kaempferol (11), quercetin (12), quercitrin (13), and rutin (14) were purchased from Sigma Chemical Co. (St. Louis, MO, U.S.A). Polyoxin D and nikkomycin Z, purchased from Calbiochem Co. (U.S.A), were used as standard compounds in this study. Polyoxin D and nikkomycin $\mathrm{Z}$ were dissolved in distilled water (4)

\section{3-O-Galloyl-(-)-shikimic acid (3): m.p. $225^{\circ} \mathrm{C} .[\alpha]_{\mathrm{D}}^{29}:-110.9^{\circ}(\mathrm{c}$ 0.4 , acetone)}

Corilagin (4): m. p. $211-212^{\circ} \mathrm{C} .[\alpha]_{\mathrm{D}}^{26}$ : $-230.2^{\circ}($ c 0.9, MeOH).

Geraniin (5): m. p. $218-221^{\circ} \mathrm{C} .[\alpha]_{\mathrm{D}}^{28}:-147.8^{\circ}($ c $0.9, \mathrm{MeOH})$.

Quercetin-3-O-(2"-O-galloyl)- $\beta$-D-glucoside (6): m.p. $205^{\circ} \mathrm{C}$. $[\alpha]_{\mathrm{D}}^{20}:-129^{\circ}(\mathrm{c} 0.1, \mathrm{MeOH})$

Kaempferol-3-0-(2"-0-galloyl)- $\beta$-D-glucoside (7): m.p. 227$229^{\circ} \mathrm{C} .[\alpha]_{\mathrm{D}}^{20}:-85^{\circ}($ c $0.9, \mathrm{MeOH})$.

\section{Results and Discussion}

In the course of our screening program for chitin synthase II inhibitors from natural resources, we found that the $80 \%$ aqueous acetone extract of aerial parts of Euphorbia pekinensis strongly inhibited chitin synthase II from Saccharomyces cerevisiae. Chitin synthase II assay-directed separation yielded seven tannins and related compounds; gallic acid (1), methyl gallate (2), 3-0-galloyl-(-)-shikimic acid (3), corilagin (4), geraniin (5), quercetin-3-O-(2"-O-galloyl)- $\beta$-D-glucoside $(\mathbf{6})$, and kaempferol-3-O-(2"-O-galloyl)- $\beta$-D-glucoside (7). The structures of compounds 1-7 were previously reported $(3-8)$. Among them, compounds $\mathbf{6}$ and $\mathbf{7}$ gave a positive response in $\mathrm{FeCl}_{3}$ and $\mathrm{Mg}-\mathrm{HCl}$ tests and showed absorption bands for a glycosidic linkage at $1050 \mathrm{~cm}^{-1}$ (glycosidic C-O) in their IR spectra, indicating a flavonoid glycoside. Acid hydrolysis of both compounds with $5 \% \mathrm{H}_{2} \mathrm{SO}_{4}$ yielded glucose and gallic acid along with quercetin (12) from compound $\mathbf{6}$, and kaempferol (11) for compound 7. The ${ }^{1} \mathrm{H}-\mathrm{NMR}$ spectrum of compound 6 showed an anomeric proton signal at $6.02\left(1 \mathrm{H}, \mathrm{H}-1^{\prime \prime}\right)$ and a galloyl proton signal at $\delta=7.32(2 \mathrm{H}$, galloyl $\mathrm{H}-2$ and $\mathrm{H}-$ 
<smiles>O=C(O)c1cc(O)c(O)c(O)c1</smiles><smiles>COC(=O)c1cc(O)c(O)c(O)c1</smiles><smiles>O=C(O)C1CC(O)C(O)C(O)C1</smiles>

$$
\begin{aligned}
& 3: \mathrm{R}=\mathrm{Gal} \\
& \mathbf{9}: \mathrm{R}=\mathrm{H}
\end{aligned}
$$<smiles>[Y]C(C)(O)C(O)(O)C(=O)Oc1oc2cc(O)cc(O)c2c(=O)c1-c1ccc(O)c(O)c1</smiles>
$6: R=O H$
7<smiles>O=C(O)C1(O)CC(O)C(O)C1O</smiles>

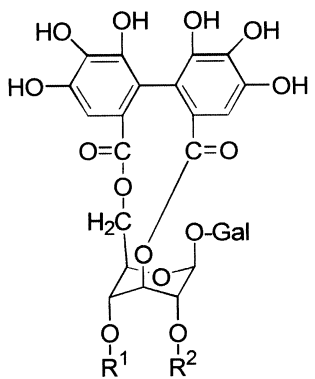

$4: \mathrm{R}^{1}=\mathrm{R}^{2}=\mathrm{H}$

$5: R^{1}+R^{2}=D H H D P$

Fig. 1 Structures of compounds used in this study.<smiles>O=C1Oc2c(O)c3cc(O)c2OC(=O)c2cc(O)c(O)c(c2-3)OC1=O</smiles>

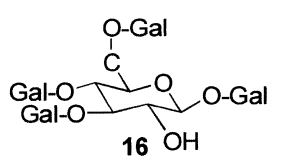<smiles>[R]Cc1cc(O)c(O)c2c1O[C@@]1(O)O[C@]2(O)C(=O)C=C1C([R])=O</smiles>
DHHDP<smiles>[R]c1cc(-c2oc3cc(O)cc(O)c3c(=O)c2[R])ccc1O</smiles>

$$
11: R^{1}=R^{2}=H
$$$$
12: \mathrm{R}^{1}=\mathrm{OH}, \mathrm{R}^{2}=\mathrm{H}
$$

$13: \mathrm{R}^{1}=\mathrm{OH}, \mathrm{R}^{2}=$ rhamnose

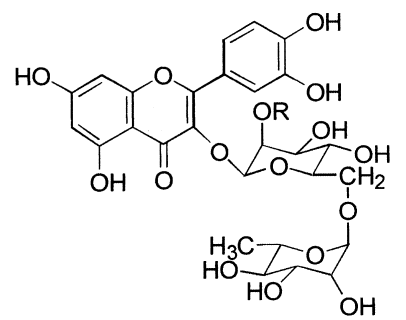

$14: \mathrm{R}=\mathrm{OH}$
$15: \mathrm{R}=\mathrm{Gal}$
6), suggesting the presence of one mole of glucoside and galloyl. In addition, compound 6 showed five proton signals characteristic of quercetin, three aromatic signals at $\delta=7.03$ $\left(1 \mathrm{H}, \mathrm{H}-3^{\prime}\right), 7.71\left(1 \mathrm{H}, \mathrm{H}-2^{\prime}\right)$ and $7.91\left(1 \mathrm{H}, \mathrm{H}-6^{\prime}\right)$ for 1,4,5-trisubstituted benzene (B ring), and two doublet signals at $\delta=6.31$ $(1 \mathrm{H}, \mathrm{H}-7)$ and $6.60(1 \mathrm{H}, \mathrm{H}-9)$ for the A-ring of flavonoid. The ${ }^{1} \mathrm{H}$-NMR spectrum of compound $\mathbf{7}$ was similar to that of compound 6 except for $\mathrm{H}^{-5^{\prime}}(\delta=6.92,2 \mathrm{H})$. On the basis of the UV spectrum, ${ }^{1} \mathrm{H}$ - and ${ }^{13} \mathrm{C}-\mathrm{NMR}$ spectra, and ${ }^{1} \mathrm{H}^{-1} \mathrm{H}$ COSY spectrum, for compounds $\mathbf{6}$ and $\mathbf{7}$, it was suggested that the C-2" of glucoside was ester-linked to gallic acid. Therefore, compounds 6 and 7 were determined to be quercetin-3-O- $(2$ "- $-O$ galloyl $)-\beta$-D-glucoside and kaempferol-3-O-(2"-O-galloyl)- $\beta$-Dglucoside, respectively, whose spectral data were consistent with those reported in the literature $(5-10)$.

With regard to the inhibitory activities of compounds 1-16 (Fig.1), chitin synthases II and III from S. cerevisiae ECY38$38 \mathrm{~A}$ (pAS6) and S. cerevisiae ECY38 - 38A (pWJC6), respectively, were used, and the activities were measured by the formation of chitin from UDP-[U- $\left.{ }^{14} \mathrm{C}\right]-\mathrm{N}$-acetylglucosamine. The inhibitory activities of the compounds can be compared with the positive controls, polyoxin D and nikkomycin $Z$, known chitin synthase II and III inhibitors with IC $_{50}$ values of 134 and
$1 \mu \mathrm{M}$, respectively. The inhibitory activities of these compounds against chitin synthases II and III are shown in Table $\mathbf{1}$. Compounds 1-7 and 10-16 dose-dependently inhibited chitin synthase II activity. Phenolic compounds 1, 2, and $\mathbf{1 0}$ showed weak or similar inhibitory activity against chitin synthase II with $\mathrm{IC}_{50}$ values of $87-206 \mu \mathrm{M}$. In addition, tannins (3-7, 15, and 16) and related flavonoids (11-14) exhibited strong inhibitory activities against chitin synthase II with $\mathrm{IC}_{50}$ values of $18-54 \mu \mathrm{M}$, which is $2.5-7.5$ times stronger inhibitory activity than that of polyoxin D. On the other hand, two organic acids, $(-)$-quinic acid (8) and (-)-shikimic acid (9), did not exhibit inhibitory activity against chitin synthase II, whereas 3-O-galloyl-(-)-shikimic acid (3), having a (-)-shikimic acid moiety, was the most potent inhibitor with an $\mathrm{IC}_{50}$ value of $18 \mu \mathrm{M}$. In contrast, compounds 1-16 demonstrated little or no inhibitory activity against chitin synthase III.

From the results of these experiments, it was found that the degree of inhibition of chitin synthase II was in the order of tannins $>$ flavonoids $>$ phenolic acids. The results suggested these compounds (except that organic acids) could specifically inhibit the chitin synthase II. Therefore, compounds 1-7 and 10-16 may be useful lead compounds for development of antifungal agents through the control of chitin biosynthesis. 
Table 1 Inhibitory activities of tannins and related compounds against chitin synthases II (Chs II) and III (Chs III)

\begin{tabular}{|c|c|c|c|}
\hline Compounds & M. W. & $\begin{array}{l}\text { IC } 50 \text { against } \\
\text { Chs II }(\mu \mathrm{M})\end{array}$ & $\begin{array}{l}\text { Inhibitory activity } \\
\text { against Chs III at } \\
280 \mu \mathrm{g} / \mathrm{ml}(\%)\end{array}$ \\
\hline \multicolumn{4}{|l|}{ Phenol and phenolic acids } \\
\hline Gallic acid (1) & 170 & 206 & 0 \\
\hline Methyl gallate (2) & 184 & 87 & 0 \\
\hline Ellagic acid (10) & 302 & 149 & 0 \\
\hline \multicolumn{4}{|l|}{ Organic acids } \\
\hline (-)-Quinic acid (8) & 192 & 0 & $<10$ \\
\hline (-)-Shikimic acid (9) & 174 & 0 & $<15$ \\
\hline \multicolumn{4}{|l|}{ Flavonoids } \\
\hline Kaempferol (11) & 286 & 52 & 0 \\
\hline Quercetin (12) & 302 & 36 & 0 \\
\hline Quercitrin (13) & 448 & 45 & 0 \\
\hline Rutin (14) & 610 & 54 & 0 \\
\hline \multicolumn{4}{|l|}{ Tannins } \\
\hline $\begin{array}{l}\text { 3-O-galloyl-(-)- } \\
\text { shikimic acid (3) }\end{array}$ & 326 & 18 & 0 \\
\hline Corilagin (4) & 634 & 25 & 0 \\
\hline Geraniin (5) & 952 & 30 & 0 \\
\hline $\begin{array}{l}\text { Quercetrin-3-O-(2"-O- } \\
\text { galloyl)- } \beta \text {-D-glucoside (6) }\end{array}$ & 616 & 21 & 0 \\
\hline $\begin{array}{l}\text { Kaempferol-3-O-(2"-O- } \\
\text { galloyl)- } \beta \text {-D-glucoside (7) }\end{array}$ & 600 & 50 & 0 \\
\hline $\begin{array}{l}\text { Quercetrin-3-O-(2"-O- } \\
\text { galloyl)- } \beta \text {-D-rutinoside (15) }\end{array}$ & 762 & 37 & 0 \\
\hline $\begin{array}{l}\text { 1,3,4,6-tetra-O-galloyl- } \\
\beta \text {-D-glucoside (16) }\end{array}$ & 788 & 23 & 0 \\
\hline Polyoxin D & 521 & 134 & $>95^{a}$ \\
\hline Nikkomycin Z & 495 & 273 & $>95^{a}$ \\
\hline
\end{tabular}

${ }^{a} \mathrm{IC}_{50}$ values for Chs III of both compounds were 2 and $1 \mu \mathrm{M}$, respectively.

Euphorbia pekinensis is known to be rich in tannins and has shown diverse biological and pharmacological actions such as antiviral, antibacterial and antioxidative activities. Compounds 1-16 have also shown antibacterial (11), anti-tyrosinase (12), antitumor (13), and astringent activity (14). However, this is the first report demonstrating these compounds specifically inhibit the chitin synthase II. In previous papers (15), (16), we have reported that several phenolic compounds such as flavonoids and triterpenoids from higher plants showed a specific inhibitory activity against chitin synthase II. Taken together, these phenolic compounds, as potential inhibitors of chitin synthase II, should be investigated in more detail.

\section{Acknowldegements}

We thank Dr. E. Cabib (NIH, USA) for providing the recombinant $S$. cerevisiae ECY38-38A (pAS6) and $S$. cerevisiae ECY38-38A (pWJC6) strains. This work was supported by a grant (PF 002110-03) from Plant Diversity Research Center of 2/st Frontier Research Program launched by Ministry of Science and Technology of Korean government.

\section{References}

${ }^{1}$ Cabib E, Roberts S, Bowers B. Synthesis of the yeast cell wall and its regulation. Annual Review of Biochemistry 1982; 51: 763-93

${ }^{2}$ Cabib E, Sburlati A, Bowers B, Silverman SJ. Chitin synthase I, an auxiliary enzyme for chitin synthesis in Saccharomyces cerevisiae. Journal of Cell Biology 1989; 108: 1665-72

${ }^{3}$ Choi WJ, Cabib E. The use of divalent cations and $\mathrm{pH}$ for the determination of specific yeast chitin synthases. Analytical Biochemistry 1994; 219: $368-72$

${ }^{4}$ Hwang EI, Kim YK, Lee HB, Kim HG, Kim SU. Screening system for chitin synthase II inhibitors from natural resources and its inhibitor prodigiosin. Journal of Microbiology \& Biotechnology 2000; 10: $251-7$

${ }^{5}$ Matsuda $\mathrm{H}$. Studies on the constituents of the leaves of Rhus and of some species of related genera in Japan. Chemical \& Pharmaceutical Bulletin 1966; 14: 877-83

${ }^{6}$ Nonaka G, Ageta M, Nishioka I. Tannins and related compounds. XXV. A new class of gallotannins possessing a (-)-shikimic acid core from Castanopsis cuspidate var. sieboldii Nakai (1). Chemical \& Pharmaceutical Bulletin 1985; 3: 96-101

${ }^{7}$ Lee SH, Tanaka K, Nonaka G, Nishiok I, Zhang B. Allose gallates from Euphorbia fischeriana. Phytochemistry 1991; 30: 1251-3

${ }^{8}$ Okuda T, Hatano T, Yazaki K. Dehydrogeraniin, furosinin and furosin, dehydroellagi-tannins from Geranium thunbergii. Chemical \& Pharmaceutical Bulletin 1982; 30: $1113-6$

${ }^{9}$ Ishimura K, Nonaka G, Nishioka I. Gallic acid esters of protoquercitol, quinic acid and (-)-shikimic acid from Quercus mongolica and Q. myrsinaefolia. Phytochemistry 1987; 26: $1501-4$

${ }^{10}$ Isobe T, Fukushige T, Noda Y. A new flavonoid glycoside from Polygonum nodosum. Chemistry Letters 1979: 27-30

${ }^{11}$ Chung KT, Lu Z, Chou MW. Mechanism of inhibition of tannic acid and related compounds on the growth of intestinal bacteria. Food \& Chemical Toxicology 1998; 36: 1053-60

${ }^{12}$ Matsuo K, Kobayashi M, Takuno Y, Kuwajima H, Ito H, Yoshida T. Anti-tyrosinase activity constituents of Arctostaphylos uva-ursi. Yakugaku Zasshi 1997; 117: 1028-32

${ }^{13}$ Gali HU, Perchellet EM, Klish DS, Johnson JM, Perchellet JP. Antitumor-promoting activities of hydrolysable tannins in mouse skin. Carcinogenesis 1992; 13: 715-8

${ }^{14}$ Schiffman SS, Suggs MS, Simon SA. Astringent compounds suppress taste responses in gerbil. Brain Research 1992; 595: 1-11

${ }^{15}$ Kim SU, Hwang EI, Nam JY, Son KH, Bok SH, Kim HE, Kwon BM. Inhibition of chitin synthase II by catechins from stem bark of Taxus cuspidata. Planta Medica 1999; 65: 97-8

${ }^{16}$ Jeong TS, Hwang EI, Lee HB, Lee ES, Kim YK, Bae KH, Bok SH, Kim SU. Chitin synthase II Inhibitory activity of ursolic acid, isolated from Crataegus pinnatifida. Planta Medica 1999; 65: $261-3$

Sung-Uk Kim, Ph. D.

Antibiotics Research Laboratory,

Korea Research Institute of

Bioscience and Biotechnology

P. O. Box 115 Yusung,

Taejon 305-333,

Republic of Korea

Fax: +82-42-861-2675

E-mail: kimsu@mail.kribb.re.kr

Tel. +82-42-860-4554 